
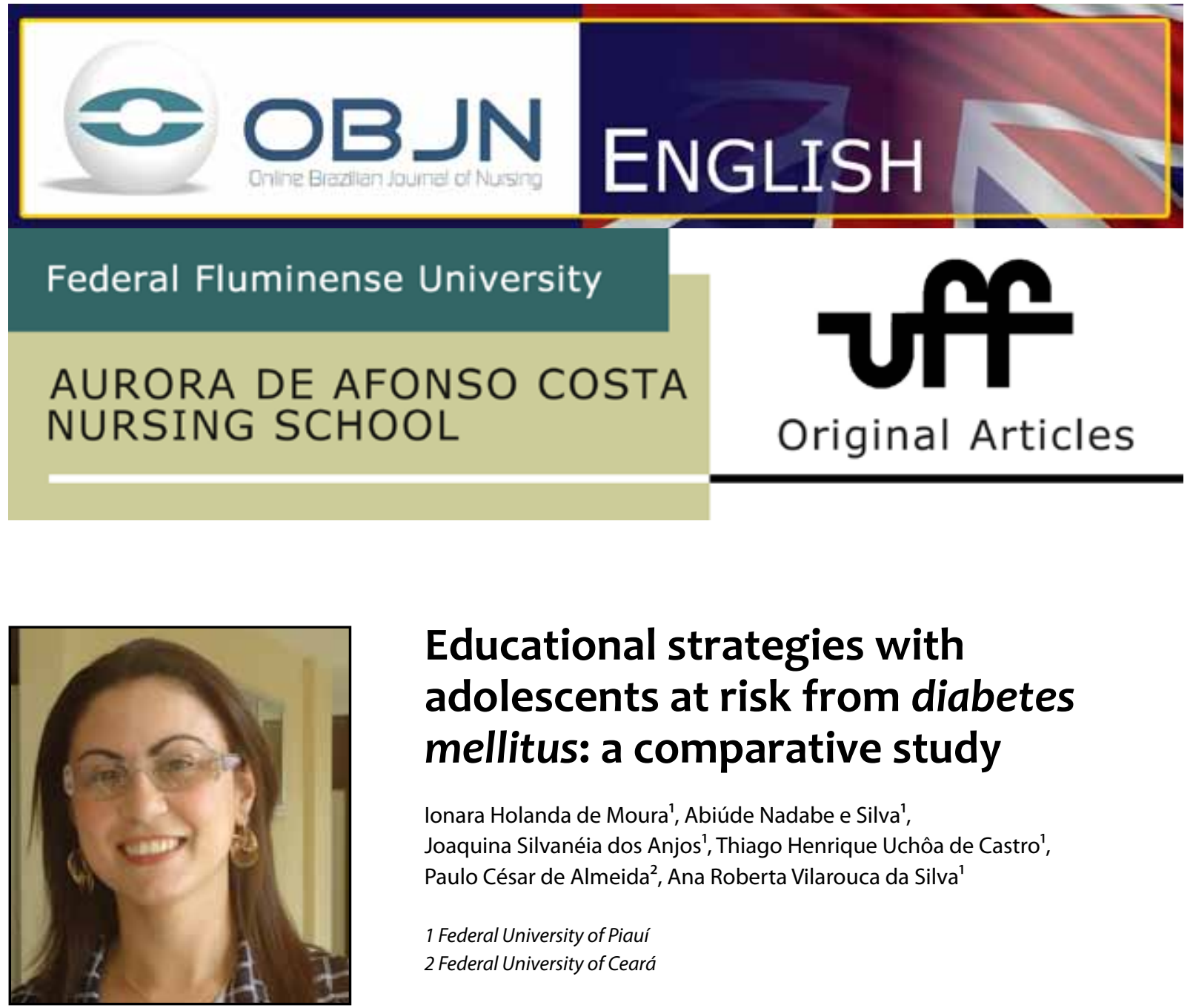

\title{
Educational strategies with adolescents at risk from diabetes mellitus: a comparative study
}

\author{
Ionara Holanda de Moura', Abiúde Nadabe e Silva', \\ Joaquina Silvanéia dos Anjos ${ }^{1}$, Thiago Henrique Uchôa de Castro', \\ Paulo César de Almeida ${ }^{2}$, Ana Roberta Vilarouca da Silva ${ }^{1}$ \\ 1 Federal University of Piauí \\ 2 Federal University of Ceará
}

\section{ABSTRACT}

Aim: To compare the knowledge and behavior of adolescents with risk factors associated with type 2 diabetes mellitus after the implementation of two educational strategies. Method: Comparative and intervention study with the participation of 60 students from two public schools divided into two groups: $G A(n=30)$ and $G B(n=30)$. GA received individual educational intervention, while $G B$ had group educational intervention. We used questionnaires to assess the level of knowledge prior to intervention, in the day after it, and 60 days after the interventions, when we also assessed the intention of changing habits. Results: There was a statistically significant increase in the level of knowledge as a result of both interventions. By comparing GA and GB after the interventions, we observed that the intention to change habits were similar in both groups. Conclusion: Both educational interventions were effective in raising knowledge and can be used in schools for the prevention of T2DM in at-risk adolescents.

Descriptors: Primary Care Nursing; Nursing; Public Health Nursing; Health Education; Diabetes Mellitus. 


\section{INTRODUCTION}

Type 2 diabetes mellitus (T2DM) is a disease that is prevalent worldwide ${ }^{(1)}$. It is estimated that by the year 2030, worldwide, 300 million people will suffer from diabetes, and that this disease will be a leading cause of death ${ }^{(2)}$. In Brazil, $9.7 \%$ of people over 35 years of age have diabetes $^{(3)}$. However, T2DM appears to have been affecting the population at increasingly younger ages.

A study investigating the risk factors for T2DM in 794 adolescents in Fortaleza (CE) found that 39\% had at least two risk factors with regard to type 2 diabetes. Most such risk factors identified in this study are modifiable, and could be subject to preventive interventions in the school context ${ }^{(4)}$.

T2DM, until recently, was considered a rare disease in adolescence. However, in recent decades, in industrialized countries, several authors have reported a large increase in the incidence of T2DM among adolescents, with similar characteristics to those of adults. The outbreak of cases of T2DM in childhood and adolescence is a consequence of the global obesity epidemic and the lack of physical activity. Currently, more than 200 children and adolescents develop the disease every day ${ }^{(5)}$.

Given the magnitude of the problem, there emerges the need to channel efforts to prevent T2DM in children and adolescents. The prevention of this health problem opens a field of action for health professionals, either at the primary or secondary levels. Among the primary measures we highlight the identification and intervention of risk factors aiming at their control and reduction ${ }^{(6)}$.

In this context, education is a key area for the prevention of diabetes, given that it is ethically favorable to update the human potential to act on the environment (behavior change), so that we can achieve health promotion. In terms of initiatives encompassing disease prevention, or combating and treating risk factors, the literature, in general, designates the need for educational or health education programs. Regarding these programs, generally, the literature discourse refers to structured and unstructured forms.

The objective of this study was to compare the knowledge and the attitude of adolescents with risk factors for T2DM after the implementation of two educational strategies, and to measure the effectiveness of individual and group educational strategies. The sample was characterized in terms of socioeconomic variables, comparing the scores in terms of knowledge at the beginning, immediately after, and 60 days after the implementation of the two different educational strategies (folder-individual; formal-group), analyzing the behavior of adolescents with risk factors for T2DM.

\section{METHOD}

This is a comparative and intervention study with a prospective cohort, carried out from 2011 to 2012. Adolescents of both genders, aged between 11 and 19 years, enrolled in three schools from the public education network in the municipality of Picos, Piauí, Northeastern Brazil, participated in the study. The sample was selected by consulting the database built from the research into risk factors for T2DM in public school students from Picos in 2010.

The inclusion criteria used were: having at least one modifiable risk factor for T2DM (overweight, sedentary lifestyle, high waist circumference level, high blood glucose and/or blood pressure levels, poor eating habits) and be attending school during the period of data 
collection. We excluded T2DM-confirmed cases, and adolescents with cognitive and/or reading or writing impairment.

For the sample size calculation, we used the formula adapted to situations that, a priori, involve two predefined groups $^{(7)}$. The sample consisted of 60 adolescents, who were divided into two groups designated as GA and $G B$, with 30 participants in each. The GA group received individual educational intervention while the GB group had group intervention.

Data collection was not conducted simultaneously in both groups due to the strike in state schools: in GA, it occurred from December 2011 to March 2012; in GB, between from March to June 2012.

The allocation of participants in groups was done randomly, and the students did not know to which group they belonged. A questionnaire was used to assess the level of knowledge and change in habits before and after the educational interventions.

The level of knowledge before and after intervention was classified into six categories ${ }^{(8,9)}$. Thus, range scores from zero to 10 were applied as follows: no knowledge (zero), very little knowledge ( $<1$ to 2.9 ), little knowledge (3 to 4.9), good knowledge (5 to 6.9), more than good knowledge (7 to 8.9), very good knowledge (9-10). With regard to changes in habits, we considered this to be the intention to change on the part of the adolescents in terms of modifying their diet and introducing the practice of physical activity in their daily life ${ }^{(9)}$. This intention was self-reported as yes or no.

The following educational, individual and group interventions were conducted at schools:

- Pre-test: assessing the level of knowledge about T2DM in GA and GB groups; application of educational interventions;

- Post-test: assessing the level of knowledge about T2DM in GA and GB groups on two separate occasions: the day after the intervention, and 60 days from it. In the latter situation we also assessed the readiness for change in daily habits.

The researchers established the referred time frame according to the time estimated to develop the study.

The individual educational intervention took place in a private room in the school that was set aside for this purpose. The students were given a folder with information about T2DM (concept, signs and symptoms, acute and chronic complications, risk factors and prevention) that was read by the researcher. Encounters with groups of ten students were conducted once a week until the entire group had been dealt with.

In the educational intervention group, a program that focused on participatory education, opinions, and researcher-student interaction was applied. There were weekly meetings: the group was divided into 2 sub-groups of 15 students each. Both received the educational intervention in the same week.

The program had a total workload of 10 hours divided into 5 weekly meetings of 2 hours each, presenting the same subject covered in $\mathrm{GA}$. All the meetings initially involved interaction dynamics about T2DM. We used clippings, cardboard, glue, scissors, wood, paper, among other materials. The participants explained their prior knowledge of the subject through play, and after this the researcher did the appropriate interventions acting as a learning facilitator. In the first meeting the concept of the disease, and signs and symptoms were discussed; in the second, acute and chronic complications; the third and fourth, risk factors; in the fifth, prevention.

Since the objective was to compare the knowledge and the behavior of adolescents with risk factors for T2DM after the implementation 
of two educational strategies, data analysis compared the results with regard to the level of knowledge before and after the interventions, both for GA and for GB, and between the two groups. The same procedure was performed for data obtained with regard to the intention to change their habits.

Data were organized using Excel 8.0 software and processed using Statistical Package for Social Sciences (SPSS) 17.0 for Windows. The Fisher-Freeman-Halton and Z test were used for proportions.

The study met national and international ethics in research standards involving human subjects and was conducted with the approval of the Ethics Research Committee of the Federal University of Piauí, in accordance with CAAE 0109.0.045.000-11 protocol.

\section{RESULTS}

Of the 60 adolescents, $56.7 \%$ were female. The age range was between 11 and 19 years, with mean age of 14.4 years. As for education, $81.7 \%$ were in elementary school. With regard to family monthly income, $85 \%$ reported an income from one to two minimum wages. Of the adolescents, $73.3 \%$ lived with their parents.

As regards the level of knowledge with regard to both the GA and the GB groups, there were differences between the assessments conducted before interventions, on day 1 and 60 days after the end of interventions $(p=0.0001)$.

The level of knowledge of the two groups was the same for each step - pre-test: $p=0.923$; immediate post-test: $p=0.999$; late post-test: $\mathrm{p}=0.473$.

In both groups, the mean scores on day 1 and 60 days after the end of the interventions had higher values than the average of the assessment before the start of the interventions $(p=0.0001)$ (Table 1).

Table 1. Sample distribution according to level of knowledge and test steps, after educational interventions. Picos (PI), December 2011 to June 2012.

\begin{tabular}{|c|c|c|c|}
\hline \multirow{2}{*}{$\begin{array}{c}\text { Knowledge } \\
\text { level }\end{array}$} & pre-test & $\begin{array}{c}\text { immediate } \\
\text { post test }\end{array}$ & $\begin{array}{l}\text { Delayed } \\
\text { post test }\end{array}$ \\
\hline & n (\%) & n (\%) & n (\%) \\
\hline \multicolumn{2}{|l|}{ Group A - Folder } & & $p<0,001^{*}$ \\
\hline \multirow{2}{*}{$\begin{array}{l}\text { No knowledge } \\
\text { Very little know- } \\
\text { ledge }\end{array}$} & $1(3,4)$ & $1(3,4)$ & - \\
\hline & $7(23,3)$ & - & - \\
\hline \multirow{2}{*}{$\begin{array}{l}\text { Good knowledge } \\
\text { more than good } \\
\text { knowledge }\end{array}$} & $12(40)$ & $3(10)$ & $7(23,3)$ \\
\hline & $7(23,3)$ & $12(40)$ & $14(46,7)$ \\
\hline $\begin{array}{l}\text { Very good know- } \\
\text { ledge }\end{array}$ & $3(10)$ & $14(46,6)$ & $9(30)$ \\
\hline \multicolumn{3}{|c|}{ Group B - Structured } & $\mathrm{p}<0,001^{*}$ \\
\hline \multirow{2}{*}{$\begin{array}{l}\text { No knowledge } \\
\text { Very little know- } \\
\text { ledge }\end{array}$} & $1(3,3)$ & - & $1(3,5)$ \\
\hline & $7(23,3)$ & $1(3,4)$ & $2(7,1)$ \\
\hline \multirow{2}{*}{$\begin{array}{l}\text { Good knowledge } \\
\text { more than good } \\
\text { knowledge }\end{array}$} & $13(43,3)$ & $3(10)$ & $7(25)$ \\
\hline & $8(26,8)$ & $12(40)$ & $9(32,2)$ \\
\hline $\begin{array}{l}\text { Very good know- } \\
\text { ledge }\end{array}$ & $1(3,3)$ & $14(46,6)$ & $9(32,2)$ \\
\hline $\mathrm{p}$ & $0,923^{* *}$ & & $0,999^{* *}$ \\
\hline \multicolumn{4}{|c|}{$\begin{array}{l}{ }^{*} \text { Comparing level of knowledge x stage; }{ }^{* *} \text { Comparison } \\
\text { between pre-test, immediate and delayed post-tests } \\
\text { Fisher-Freeman-Halton test. } \\
\text { Source: Authors' data }\end{array}$} \\
\hline
\end{tabular}

\section{Behavior change}

Regarding eating habits, there was a change in the lifestyle of the two groups $(p=0.001$ and $p=0.004$ for $G A$ to $G B$ ). However, in terms of physical activity, there was only change in $G B(p<0.0001$ Table 2). It is noteworthy that the children of the GA and GB groups who failed to change their eating habits and introduce the practice of physical activity on a daily basis claimed a lack of interest and/or that the strategies used were insufficient to motivate them. 
Table 2. Distribution of adolescent students, according to referred behavior after 60 days from the implementation of educational activity. Picos (PI), December 2011 to June 2012.

\begin{tabular}{lcc}
\hline $\begin{array}{c}\text { Change in } \\
\text { lifestyle }\end{array}$ & Diet habits & $\begin{array}{c}\text { Physical acti- } \\
\text { vity }\end{array}$ \\
\hline & $\mathbf{n}(\%)$ & $\mathbf{n}(\%)$ \\
\hline Grupo A & $\mathrm{p}<0,001$ & $\mathrm{p}>1,000$ \\
Sim & $17(50,0)$ & $18(26,7)$ \\
Não & $13(10,0)$ & $12(26,7)$ \\
Grupo B & $\mathrm{p}<0,004$ & $\mathrm{p}<0,0001$ \\
Sim & $20(64,3)$ & $27(53,6)$ \\
Não & $8(14,3)$ & $1(3,6)$ \\
\hline
\end{tabular}

$Z$ test for proportion

Source: Authors' data

\section{DISCUSSION}

Group or individual education is an indispensable tool with regard to the adequacy of behavior and conduct, and thus can help prevent chronic diseases such as T2DM. Health education initiatives developed with proper planning, and based on the construction of knowledge, achieve good results. The findings of this study indicate that both the individual and group educational strategies can be used effectively in health promotion.

The results also show that, after the implementation of the educational intervention, adolescents increased their knowledge in the immediate and delayed post-test in both the GA and the GB groups. This was also observed in other research which evaluated two educational strategies for the prevention of T2DM in adolescents with risk factors, showing that, in the immediate post-test and group strategy, respectively $64.4 \%$ and $13.4 \%$ presented "more than good" and "very good" knowledge rates, whereas individually, these values were $57.8 \%$ and $22.2 \%$. In the post-60-day assessment, $55.5 \%$ and $13.4 \%$ demonstrated "more than good" and "very good" knowledge; whereas individually, the results were $66.7 \%$ and $4.4 \%{ }^{(9)}$.

Another study conducted in order to verify the knowledge and behavior of people with diabetes mellitus who participated in an education program for self-care in diabetes, revealed that $78.05 \%$ had higher scores in terms of knowledge of diabetes, indicating knowledge and understanding of the disease ${ }^{(10)}$. In addition, the work performed in order to compare the effectiveness of educational program strategies in diabetes, in groups and individually, showed that the group education intervention had better glycemic control results than did the individual(11).

The results of a study conducted in Minas Gerais showed the importance of education and communication in health, based on dialogical relations and the promotion of popular knowledge, by reorienting the educational practices for self-care, in order to establish strategies to prevent and control the disease ${ }^{(12)}$.

Regarding the change of behavior regarding diet after intervention, both in the group and individual strategies, the research found that less than half ( $40 \%$ and $31.1 \%$, respectively) was able to change their eating habits. With regard to physical activity, the study showed that in the group, more than half (62.2\%) of the adolescents had managed to introduce this practice into their daily lives; individually this value was lower $(46.7 \%)^{(9)}$. Other research found that, regarding behavior, the scores ranged from 25 to 71 , suggesting difficulty in coping with the disease ${ }^{(10)}$.

There is a need for the development of programs and educational strategies that provide a learning space for the individual ${ }^{(13)}$. In this context, the school plays an important role in the formation of healthy habits on the part of adolescents $^{(14)}$.

This study, however, had some limitations, such as the short follow-up period and the fact that it was not monitored. A review the results 
would be appropriate, over time, to confirm that this change of knowledge impacted on the daily life and changed the habits of the students involved.

\section{CONCLUSION}

Given the identified results, we stress the importance of promoting health education as a way to promote knowledge and therefore encourage changes in lifestyle, in order to achieve the quality of life required for every citizen. It is worth stressing that both the formal structured educational intervention in groups and the individual intervention (folder) are of value in this process, confirming the results obtained in this study of T2DM. Thus, all those involved in the health sector (professionals, scholars and managers, among others) should make efforts to increase and prioritize the practice in many different environments, in order to reach all the users of the health service.

Considering the good results of the two educational strategies, it is important that more studies of this type be performed in order to increasingly focus on the school environment in order to educate pupils about the need for preventive action against T2DM.

\section{REFERENCES}

1. Diógenes MAR, Souza AKP, Cavalcante IP, Lopes LCO, Rebello MMCB. Insulin therapy: knowledge and practices used by patients with type 2 diabetes mellitus. Rev. enferm. UERJ. 2012 dez; 20(esp.2): 746-51.

2. Sociedade Brasileira de Diabetes. Diretrizes da Sociedade Brasileira de Diabetes 2003-2014.. São Paulo: AC Farmacêutica; 2014.

3. Medeiros CC, Bessa GG, Coura AS, França IS, Sousa FS. Prevalence of risk factors for diabetes mellitus among public servants [Internet]. Rev Eletr Enf. 2012;14(3):559-69 [cited 2013 ago 10]. Available from: http://www.fen.ufg.br/fen_revista/v14/n3/ pdf/v14n3a12.pdf

4. Vasconcelos HC, Araújo MF, Damasceno MM, Almeida PC, de Freitas RW. Risk factors for type 2 diabetes mellitus among adolescents. Rev EsC Enferm USP. 2010;44(4):881-7.

5. Armed S, Daneman D, Mahumad FH, Hamilton J. Type 2 diabetes in children and adolescents. Expert Rev Cardiovasc Ther. 2010;8(3):393-406.

6. Costa JV, Silva AR, Moura IH, Carvalho RB, Bernardes LE, Almeida PC. An analysis of risk factors for arterial hypertension in adolescent students [Internet]. Rev. Latino-Am Enfermagem. 2012;20(2):[07 telas] [cited 2013 ago 10]. Available from: http://www.revistas.usp.br/rlae/article/ viewFile/48506/52386

7. Pocock SJ. Clinical trials - a practical approach. Great Britiain: John Wiley \& Sons; 1989.

8. Zernike W, Henderson A. Evaluating the effectiveness of two teaching strategies for patients diagnosed with hypertension. J Clin Nurs. 1998;7(1):37-44.

9. Silva $A R$, Zanetti ML, Forti AC, Freitas RW, Hissa MN, Damasceno MM. Evaluating two educational interventions to prevent type 2 Diabetes Mellitus among adolescents. Texto Contexto Enferm. 2011;20(4):782-7.

10. Rodrigues FF, Zanetti ML, Santos MA, Martins TA, Sousa VD, Teixeira CR. Knowledge and attitude: important components in diabetes education [Internet]. Rev Latino-am Enfermagem. 2009; 17 (4) [cited 2013 ago 10]. Available from: http:// www.scielo.br/pdf/rlae/v17n4/pt_06.pdf

11. Torres HC, Franco LJ, Stradioto MA, Hortale VL, Schall VT. Evaluation of group and individual strategies in a diabetes education program. Rev Saúde Pública. 2009;43(2):291-8.

12. Torres HC, Souza ER, Lima MH, Bodstein RC. Educational intervention for self-care of individuals with diabetes mellitus [Internet]. Acta Paul Enferm 2011;24(4):514-9 [cited 2013 ago 10]. Available from: http://www.scielo.br/pdf/ape/ v24n4/a11v24n4.pdf

13. Silva DAR, Lutkmeier R, Moraes MA, Souza EN. Knowledge about diabetes in patients hospitalized for heart disease:a descriptive research. 
Online Braz J Nurs. 2013; 12 (2): 222-37. Available from from: http://www.objnursing.uff.br/index. php/nursing/article/view/3876.

14. Bernardes LE, Silva ARV, Costa JV, Freitas RWJF, Karla Beatriz Alves Carvalho Campos KBAC, Deus ZLC. Practice of physical activity on the part of adolescents attending public schools: a descriptive study. Online Braz J Nurs. 2013; 12 (1): 209-17. Available from:http://www.objnursing.uff.br/ index.php/nursing/article/view/3632
All authors participated in the phases of this publication in one or more of the following steps, in According to the recommendations of the International Committee of Medical Journal Editors (ICMJE, 2013): (a) substantial involvement in the planning or preparation of the manuscript or in the collection, analysis or interpretation of data; (b) preparation of the manuscript or conducting critical revision of intellectual content; (c) approval of the versión submitted of this manuscript. All authors declare for the appropriate purposes that the responsibilities related to all aspects of the manuscript submitted to OBJN are yours. They ensure that issues related to the accuracy or integrity of any part of the article were properly investigated and resolved. Therefore, they exempt the OBJN of any participation whatsoever in any imbroglios concerning the content under consideration. All authors declare that they have no conflict of interest of financial or personal nature concerning this manuscript which may influence the writing and/or interpretation of the findings. This statement has been digitally signed by all authors as recommended by the ICMJE, whose model is available in http://www. objnursing.uff.br/normas/DUDE_eng_13-06-2013.pdf

Received: 10/22/2013

Revised: $12 / 16 / 2014$

Approved: 12/19/2014 